УДК 656.13.033.1

\title{
УПРАВЛІННЯ ЛОГІСТИЧНИМИ ПОТОКАМИ В ФОРМУВАННЯХ НАЦІОНАЛЬНОЇ ГВАРДІЇ УКРАЇНИ
}

\author{
Чухлатий А.В., доцент (НАНГУ)
}

У даній статті подано методику управління логістичними потоками в формуваннях Національної гвардї України. На основі аналізу логістичних прочесів $з$ використанням системно-логічного методу були виділені характеристики ведення взаємодї з постачальниками, які представляються в алгоритмі у вигляді об'єктів. Внаслідок специфіки воєнної економіки алгоритм був істотно змінений шляхом введення пояснюючих ознак для об'єктів-характеристик військових підрозділів та наступним усіканням ознак шляхом угруповання об'єктів. Для відбору якостей військових підрозділів у логістичних системах виконано статистичну оцінку ознак, одержуваних шляхом попарних перетинань об'єктів. Проаналізовано механізми втілення якостей у рішеннях командування військового підрозділу.

Ключові слова: логістичні потоки, управління, якості військового підрозділу, постачальник, логістичні процеси, системно-логістичний підхід

\section{УПРАВЛЕНИЕ ЛОГИСТИЧЕСКИМИ ПОТОКАМИ В ФОРМИРОВАНИЯХ НАЦИОНАЛЬНОЙ ГВАРДИИ УКРАИНЫ}

\author{
Чухлатый А.В., доцент (НАНГУ)
}

\begin{abstract}
В данной статье представлена методика управления логистическими потоками в формированиях Наџиональной гвардии Украины. На основе анализа логистических прочессов с использованием системно-логического метода были выделень характеристики ведения взаимодействия с поставщиками, которые представляются в алгоритме в виде объектов. В силу специфики военной экономики алгоритм был существенно изменен путем введения поясняющих признаков для объектов-характеристик военных подразделений и последующим усечением признаков путем группировки объектов. Для отбора качеств военных подразделений в логистических системах выполнено статистическую оценку признаков, получаемых путем попарных пересечений объектов. Проанализированы механизмы воплощения качеств в решениях командования военного подразделения.
\end{abstract}

Ключевые слова: логистические потоки, управления, качества военного подразделения, поставщик, логистические процессы, системно-логистический nодxод

\section{MANAGEMENT OF LOGISTIC FLOWS IN THE FORMATIONS OF THE NATIONAL GUARD OF UKRAINE}

\section{Chuhlaty A.V., Associate Professor (NANGU)}

In logistical processes, all efforts of the command of military units should be directed to the creation of a single, trouble-free business system for managing commercial transactions. As a result, management of logistical flows in the National Guard units of Ukraine becomes more

(C) Чухлатий А.В.

Вісник економіки транспорту і промисловості № 69, 2020 
important. In this article the method of management of logistic flows in the formations of the National Guard of Ukraine is presented. On the basis of the analysis of logistical processes using the system-logical method, the characteristics of interaction with suppliers, which are represented in the algorithm in the form of objects, were distinguished. Due to the specifics of the military economy, the algorithm was significantly modified by introducing explanatory features for military unit characteristics and subsequent truncation of features by grouping objects. To select the quality of military units in logistics systems, a statistical evaluation of features obtained by pairwise crossings of objects was performed. In order to increase the efficiency of the algorithm, truncation of multiple objects should be done. To do this, we form truncated lists of objects of the original set by grouping the objects on the same grounds for them. In order to substantiate the resulting groups and, therefore, the qualities of the business system, the similarity of objects with each other within each group is assessed. The hypothesis about the possibility of combining the corresponding objects in the aggregated qualities of military units in logistics systems is confirmed. The stats indicate that in order to increase the efficiency of the value-adding process, the selected qualities need to be embodied in the decisions of the company at different levels. The mechanisms of implementation of qualities in the decisions of the command of the military unit are analyzed. The direction of further development of this study may be the method of optimization of logistics flows in the system of logistics of military units. Thus, the conducted research made it possible to perform the structuring of object-characteristics and their features in terms of logistic activity of the military unit, to make selection of qualities of military units in logistics systems, to analyze the specifics of implementation of qualities in the decisions of the command of the military unit.

Key words: logistics flows, management, quality of military unit, supplier, logistic processes, system-logistical approach

Постановка проблеми. У логістичних процесах всі зусилля командування військових підрозділів повинні бути спрямовані на створення єдиної безвідмовної бізнес-системи управління комерційними транзакціями. Внаслідок цього актуального значення набуває управління логістичними потоками в формуваннях Національної гвардії України.

Аналіз останніх досліджень $\boldsymbol{i}$ публікацій. Питання управління логістичними процесами висвітлено у наукових працях Пушкаря О., Грабовського Є.М., Науменко М.О., Соколовського С.А., Каличевої Н.С. та ін. Зокрема, у роботах [14] аналізуються особливості інформаційної підтримки управління логістичними потоками. Веб-базовані інструменти здійснення керування системою логістики подані в дослідженнях [5-7]. Питанням якості управління логістичними потоками присвячені наукові статті [8-11].
Виділення невирішених частин загальної проблеми. Однак на сьогодні в спеціалізованій літературі відсутній методичний підхід щодо управління логістичними потоками в формуваннях Національної гвардії України.

$\begin{array}{ccr}\text { Метою } & \text { даної } & \text { cmammi } \\ \text { розроблення } & \text { методики } & \text { управління }\end{array}$ логістичними потоками в формуваннях Національної гвардії України.

Викладення основного матеріалу дослідження. Контроль процесів формування якостей військових підрозділів у логістичних системах будемо здійснювати 3 використанням алгоритму побудови узагальнень об'єктів, що відноситься до класу методів штучного інтелекту.

На основі аналізу логістичних процесів 3 використанням системнологічного методу були виділені характеристики ведення взаємодії 3 постачальниками, які представляються в алгоритмі у вигляді об'єктів. 
Внаслідок специфіки воєнної економіки алгоритм був істотно змінений шляхом введення пояснюючих ознак для об'єктів-характеристик військових підрозділів та наступним усіканням ознак шляхом угруповання об'єктів.
Для узагальнення множини об'єктів необхідно знайти ознаки - ізоморфні підознаки для частини множини, що узагальнюється.

У результаті виконаного аналізу була отримана множина об'єктів і їхніх ознак, подана в табл. 1.

Таблиияя 1

Об'єкти-характеристики та їхні ознаки

\begin{tabular}{|c|c|}
\hline Об'єкти & Ознаки \\
\hline 1 & 2 \\
\hline Гнучкість & $\begin{array}{l}\text { a) Адаптація до змін інфраструктури логістики } \\
\text { б) Можливість зміни технічних і експлуатаційних характеристик } \\
\text { відповідно до вимог споживачів } \\
\text { в) Безперервна оптимізація компонентів бізнес-системи }\end{array}$ \\
\hline Сумісність & $\begin{array}{l}\text { a) Забезпечення вбудовування в структуру бізнес-системи нових } \\
\text { компонентів } \\
\text { б) Підтримка багаторівневого об'єднання із сервісами й технологіями } \\
\text { постачальників } \\
\text { в) Сумісність технологічної платформи із програмними й апаратними } \\
\text { рішеннями провідних фірм }\end{array}$ \\
\hline Прозорість & $\begin{array}{l}\text { a) Можливість впливу споживачів на технічні й експлуатаційні } \\
\text { характеристики } \\
\text { б) Наочність структури бізнес-рішень } \\
\text { в) Можливість оптимізації компонент бізнес-системи }\end{array}$ \\
\hline Керованість & $\begin{array}{l}\text { ачів-споживачів контролювати дії комерційних } \\
\text { ні характеристики } \\
\text { ї оптимізації бізнес-рішень }\end{array}$ \\
\hline $\begin{array}{l}\text { Комерційна } \\
\text { активність }\end{array}$ & $\begin{array}{l}\text { a) Оперативна адаптація до змін моделей і умов логістики } \\
\text { б) Швидке реагування на потреби й цільові настанови споживачів } \\
\text { в) Оперативне відновлення технологічної платформи відповідно до } \\
\text { сучасних тенденцій ринку IT }\end{array}$ \\
\hline $\begin{array}{c}\text { Система } \\
\text { аутентификаг }\end{array}$ & $\begin{array}{l}\text { а) Здатність комерційних даних відновлюватися після будь-якого збою } \\
\text { системи } \\
\text { б) Наявність гнучкої системи адміністрування й системи паролів }\end{array}$ \\
\hline Регульованіс & $\begin{array}{l}\text { a) Здійснення регулювання структури бізнес-рішень за множиною } \\
\text { параметрів } \\
\text { б) Можливість оптимізації кожного елемента, задіяного в бізнес- } \\
\text { процесах }\end{array}$ \\
\hline $\begin{array}{c}\text { Партнерська } \\
\text { інтеграція }\end{array}$ & $\begin{array}{l}\text { a) Передача зовнішнім структурам традиційних функцій } 3 \text { метою } \\
\text { створення постачальницько-збутових мереж і мережевих співтовариств } \\
\text { б) Системне багаторівневе об'єднання } 3 \text { технологіями ділових партнерів } \\
\text { в) Сумісність технологічних платформ партнерів }\end{array}$ \\
\hline Надійність & $\begin{array}{l}\text { a) Наявність можливості відновлення даних } \\
\text { б) Забезпечення безпечного зв'язку компаній } 3 \text { їхніми стратегічними } \\
\text { партнерами, ключовими постачальниками й споживачами } \\
\text { в) Підтримка стабільності інформаційної бази шляхом системи } \\
\text { адміністрування та паролів }\end{array}$ \\
\hline $\begin{array}{c}\text { Персоналізація } \\
\text { послуг }\end{array}$ & $\begin{array}{l}\text { a) Реагування на зміни цільових настанов і потреб сегментів ринку } \\
\text { б) Орієнтація комерційних пропозицій на кінцевого споживача } \\
\text { в) Синхронне відновлення технологічної платформи } 3 \text { метою створення } \\
\text { зручного, зрозумілого та привабливого для споживача середовища }\end{array}$ \\
\hline
\end{tabular}


Продовження табл. 1

\begin{tabular}{|c|c|}
\hline 1 & 2 \\
\hline $\begin{array}{c}\text { Систематизо-ваний } \\
\text { BackOffice }\end{array}$ & $\begin{array}{l}\text { a) Багаторівневе об'єднання інтернет-технологій } \\
\text { б) Інтеграція бази поточних угод, бази кредитної історії, системи } \\
\text { автоматизованого складу й бухгалтерії } \\
\text { в) Стабільне функціонування системи логістики на основі інтегрованих } \\
\text { платформ організацій-партнерів }\end{array}$ \\
\hline $\begin{array}{c}\text { Чітка стратегічна } \\
\text { спрямованість }\end{array}$ & $\begin{array}{l}\text { a) Сильний інноваційний менеджмент } \\
\text { б) Орієнтація бізнесу відповідно до тенденцій світового ІТ-ринку } \\
\text { в) Побудова системи логістики, виходячи } 3 \text { потреб військового } \\
\text { підрозділу } \\
\text { г) Збільшення продажів як шляхом розвитку власної системи логістики, } \\
\text { так і за допомогою злиття з іншими компаніями, зберігаючи при цьому } \\
\text { корпоративну культуру та інтегруючи бізнес між собою }\end{array}$ \\
\hline $\begin{array}{l}\text { Виживаність у } \\
\text { конкурентному } \\
\text { середовищі, яке } \\
\text { підсилюється }\end{array}$ & $\begin{array}{l}\text { a) Об'єднання технологічних платформ } \\
\text { б) перехід компаній від «нішового» ринку логістики до надання повного } \\
\text { спектра IT-послуг, заключення партнерських угод із традиційними } \\
\text { системними інтеграторами } \\
\text { в) сумісність бізнес-рішень із партнерами }\end{array}$ \\
\hline $\begin{array}{l}\text { ERP- i CRM- } \\
\text { стандартизація } \\
\text { бізнес-процесів }\end{array}$ & 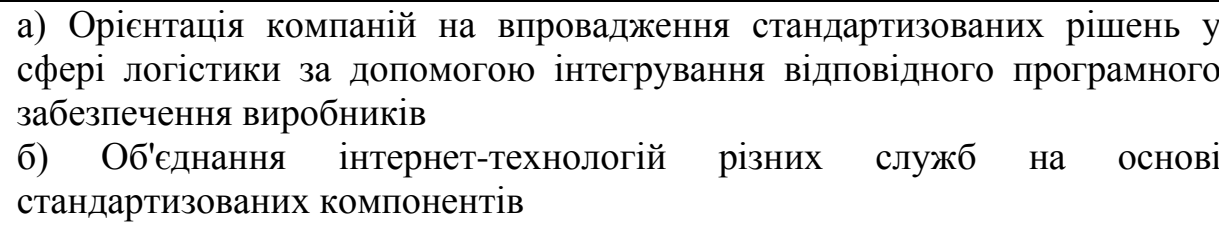 \\
\hline Безпека транзакцій & $\begin{array}{l}\text { a) Можливість відновлення даних } \\
\text { б) Наявність засобів криптографії та шифрування } \\
\text { інформації і ідентифікації користувачів } \\
\text { в) Гнучка система адміністрування та паролів }\end{array}$ \\
\hline $\begin{array}{l}\text { Маркетингова } \\
\text { ефективність }\end{array}$ & $\begin{array}{l}\text { a) Скорочення циклу розробки продукції та просування ії на ринок } \\
\text { б) Швидкий відгук торгівельної марки (бренду) на вимоги ринку } \\
\text { внаслідок орієнтації маркетингової стратегії на кінцевого споживача } \\
\text { в) Адаптація маркетингової тактики та політики до потреб і цільових } \\
\text { настанов споживачів }\end{array}$ \\
\hline
\end{tabular}

Для відбору якостей військових підрозділів у логістичних системах необхідно зробити статистичну оцінку ознак, одержуваних шляхом попарних перетинань об'єктів. 3 метою підвищення ефективності роботи алгоритму варто зробити усікання множини об'єктів. Для цього сформуємо усічені списки об'єктів вихідної множини шляхом угруповання об'єктів за однаковим для них ознакам, у результаті чого одержимо списки наступного виду:

I) гнучкість, керованість, регульованість;
II) комерційна активність, персоналізація послуг, чітка стратегічна спрямованість, маркетингова ефективність;

III) система аутентифікації, надійність, безпека транзакцій;

IV) сумісність, партнерська інтеграція, систематизований BackOffice, ERP- i CRM-стандартизація бізнеспроцесів, виживаність у конкурентному середовищі, яке підсилюється.

3 метою обгрунтування отриманих прозорість, груп i, отже, якостей бізнес-системи необхідно оцінити подібність об'єктів між 
собою в рамках кожної групи по наступній формулі:

$$
\mathrm{S}=\frac{\mathrm{W} \cdot \mathrm{E}}{\sum_{\mathrm{v}=1}^{\mathrm{W}} \mathrm{E}_{\mathrm{v}}},
$$

де $\mathrm{S}$ - ступінь подібності об'єктів;

Е - число однакових для порівнюваних об'єктів ознак;

$\mathrm{E}_{\mathrm{i}}$ - число ознак в v-ому об'єкті;

w - число об'єктів, що володіють даною ознакою;

W - загальне число об'єктів.

У результаті розрахунків одержимо:

$$
\begin{aligned}
& \mathrm{S}_{\mathrm{I}}=\frac{7}{10}=0,7 ; \mathrm{S}_{\mathrm{II}}=\frac{9}{13}=0,69 ; \\
& \mathrm{S}_{\mathrm{III}}=\frac{6}{8}=0,75 ; \mathrm{S}_{\mathrm{IV}}=\frac{10}{14}=0,71 .
\end{aligned}
$$

Як видно з результатів розрахунків, ступінь подібності об'єктів у рамках кожної групи перевищує граничної величини 0,68, тобто підтверджується гіпотеза про можливість об'єднання відповідних об'єктів в агреговані якості військових підрозділів у логістичних системах. Такими якостями військових підрозділів у логістичних системах варто вважати:
1) Відкритість - здатність військових підрозділів у логістичних системах мати достатню гнучкість i прозорість для активного впливу партнерів і постачальників на технічні та експлуатаційні характеристики 3 метою безперервної оптимізації бізнес-рішень;

2) Еластичність - якість військових підрозділів у логістичних системах, що характеризує можливість оперативного реагування та адаптації до змін моделей логістики;

3) Інформаційна безпека можливість забезпечення безпечної господарської діяльності в системі логістики та виконання ідентифікації суб'єктів логістики;

4) Синергізм - здатність підтримувати системне багаторівневе об'єднання 3 іншими технологіями, ресурсами та сервісами, забезпечувати вбудовування у свою структуру електронних бізнес-компонент i включення окремих сервісів або всієї технології в цілому в інтегрований ланцюжок бізнес-рішень системи логістики.

Для підвищення ефективності процесу додавання вартості виділені якості повинні знаходити певне втілення в рішеннях компанії різного рівня, як показано в табл. 2.

\begin{tabular}{|c|c|c|c|}
\hline Якості & \multicolumn{3}{|c|}{ Рішення } \\
\hline $\begin{array}{l}\text { інформаційної } \\
\text { структури }\end{array}$ & Стратегічні & Тактичні & Оперативні \\
\hline 1 & 2 & 3 & 4 \\
\hline Відкритість & $\begin{array}{l}\text { Персоналізація } \\
\text { інформаційної } \\
\text { сутності, створення } \\
\text { інтерфейсів взаємодії } \\
\text { робочих } \\
\text { інформаційних груп у } \\
\text { реальному часі }\end{array}$ & $\begin{array}{l}\text { Утворення } \\
\text { інформаційних } \\
\text { порталів 3 метою } \\
\text { багаторівневого } \\
\text { об'єднання різних } \\
\text { ресурсів і сервісів і } \\
\text { максимальне } \\
\text { наближення до } \\
\text { потреб } \\
\text { постачальників }\end{array}$ & $\begin{array}{lr}\text { Обмін } & \text { посиланнями, } \\
\text { просування } & \text { за } \\
\text { допомогою } & \text { пошукових } \\
\text { систем i } & \text { каталогів, } \\
\text { організація } & \\
\text { партнерських програм }\end{array}$ \\
\hline
\end{tabular}

Таблиия 2

Втілення якостей у рішеннях командування військового підрозділу 


\begin{tabular}{|c|c|c|c|}
\hline & & & вження \\
\hline 1 & 2 & 3 & 4 \\
\hline Еластичність & $\begin{array}{l}\text { Управління } \\
\text { логістичними } \\
\text { ланцюжками, } \\
\text { прогнозування } \\
\text { параметрів } \\
\text { маркетингового } \\
\text { бюджету }\end{array}$ & $\begin{array}{l}\text { Бренд-маркетинг, } \\
\text { контролінг } \\
\text { віртуальне } \\
\text { координування } \\
\text { ділових операцій }\end{array}$ & $\begin{array}{l}\text { Корегування } \\
\text { заходів } \\
\text { ітеративне } \\
\text { обслуговування } \\
\text { комплексу п посліді, } \\
\text { етапів } \\
\text { внутрішньогалузевих } \\
\text { бізнес-процесів }\end{array}$ \\
\hline $\begin{array}{ll}\text { Безпека } & \text { та } \\
\text { аутентифікація }\end{array}$ & $\begin{array}{l}\text { Розроблення стратегії } \\
\text { безпеки } \\
\text { корпоративної } \\
\text { мережі, } \\
\text { впровадження } \\
\text { ефективних і } \\
\text { надійних платіжних } \\
\text { систем }\end{array}$ & $\begin{array}{l}\text { Ліцензування } \\
\text { програмного } \\
\text { забезпечення й } \\
\text { інтернет-технологій, } \\
\text { створення } \\
\text { мережевих } \\
\text { магазинів } \\
\begin{array}{l}\text { маркетингових } \\
\text { систем }\end{array}\end{array}$ & $\begin{array}{l}\text { Криптографія та } \\
\text { шифрування } \\
\text { електронних угод, } \\
\text { аутентифікація } \\
\text { дебетових і кредитних } \\
\text { схем і протоколів } \\
\text { сеансу зв'язку }\end{array}$ \\
\hline Синергізм & $\begin{array}{l}\text { Інсталяція } \\
\text { комплексних сайтів } 3 \\
\text { інтегрованим потоком } \\
\text { онлайнової } \\
\text { iнформації } \\
\text { регулярним } \\
\text { технічним } \\
\text { обслуговуванням }\end{array}$ & $\begin{array}{l}\text { Реінжиніринг } \\
\text { бізнес-процесів } \\
\text { напрямку } \\
\text { вертикальної } \\
\text { інтеграції } \\
\text { виконуваних } \\
\text { функцій }\end{array}$ & $\begin{array}{l}\text { Інтеграція систем } \\
\text { управління сервісами та } \\
\text { iнформаційно- } \\
\text { технологічними } \\
\text { процесами }\end{array}$ \\
\hline
\end{tabular}

Висновок. Таким чином, проведене дослідження дозволило виконати структуризацію об'єктів-характеристик та їхні ознаки в умовах логістичної діяльності військового підрозділу, зробити відбір якостей військових підрозділів $\mathrm{y}$ логістичних системах, проаналізувати специфіку втілення якостей у рішеннях командування військового підрозділу.

Напрямком подальшого розвитку даного дослідження може стати методика оптимізації логістичних потоків у системі матеріально-технічного забезпечення військових підрозділів.

\section{ПЕРЕЛІК ВИКОРИСТАНИХ ДЖЕРЕЛ}

1. Pushkar O., Hrabovskyi Y. Methodology for developing an intelligent user interface for educational publications in the elearning system. Development Management. 2019.№ $\quad$ 17(3). $\quad$ P. $\quad$ 23-34. Doi:10.21511/dm.17(3).2019.03
2. Соколовський С. А., Науменко М. O., Черкашина М. В. Удосконалення управління трудовими ресурсами організації. Бізнес Інформ. 2015. № 3. С. 288-292.

3. Hrabovskyi Y., Yevsyeyev O. Development of methodological principles of support-preservation engineering work. Технолоічний аудит і резерви виробництва. 2018. №2/2. С. 43-49

4. Соколовський С. А, Науменко М. О. Аналіз особливостей управління інформаційними потоками логістичних процесів підрозділів Національної гвардії України. ScienceRise. 2018. № 2. С. 19-21.

5. Naumenko M., Hrabovskyi Y., Elaboration of methodology for designing a publishing and printing web portal. EasternEuropean Journal of Enterprise Technologies. 2018. № $2 / 2$ (92), pp. 14 - 22. DOI: 10.15587/1729-4061.2018.126305

6. Hrabovskyi Y., Brynza N, Vilkhivska O. Development of information visualization methods for use in multimedia applications. 
EUREKA: Physics and Engineering. 2020. № 1, pp. $3-17$.

7. Martins P., Zacarias M. A Web-based Tool for Business Process Improvement. International Journal of Web Portals. 2017. Volume 9. Issue 1. P. $68 \quad-84$ DOI: https://doi.org/10.4018/IJWP.2017070104

8. Грабовський С. М. Аналіз використання мультимедійних компонентів в сучасних технологіях мобільного навчання. Scientific Journal «ScienceRise». 2019. № 4(57). C. $46-50$

9. Науменко М.О. Вдосконалення управління якістю продукції високотехнологічних підприємств. Вісник економіки транспорту і промисловості. 2018. Вип. 62. С. 335-342.

10. Каличева Н.С., Маслова В.О. Логістичні підходи, як основа раціональної організації виробничого процесу на підприємстві. Вісник економіки транспорту $i$ промисловості. 2014. № 47. С. 83 - 86.

11. Каличева Н.Є., Копачевська Ю. А. Вплив логістики на розвиток підприємств малого бізнесу в сучасних умовах господарювання. Науковий вісник УжНУ. Серія: Міжнародні економічні відносини та світове господарство. 2018. Випуск 20. Ч. 2. C. $11-14$.

\section{REFERENCES}

1. Pushkar O., Hrabovskyi Y. (2019). Methodology for developing an intelligent user interface for educational publications in the elearning system. Development Management. № 17(3). P. 23-34. Doi:10.21511/dm.17(3).2019.03.

2. Sokolovsky S. A., Naumenko M. O., Cherkashina M. V. (2015) . Udoskonalennya upravlinnya trudovy'my' resursamy` pidpry`yemstva. [Improvement of the management of labor resources of the enterprise]. Business Inform. № № 3, pp. 288-292.

3. Hrabovskyi Y. Yevsyeyev O. (2018). Development of methodological principles of support-preservation engineering work. Technological audit and production reserves. №2/2. C. 43-49.

4. Sokolovskyi S. A., Naumenko N. A. (2018). Analiz osobly`vostej upravlinnya informacijny`my` potokamy` logisty`chny`x procesiv pidrozdiliv Nacional'noyi gvardiyi Ukrayiny. [Analysis of peculiarities of management of information flows of logistic processes of units of the National Guard of Ukraine]. ScienceRise. No 2, pp. 19-21.

5. Naumenko M., Hrabovskyi Y. (2018). Elaboration of methodology for designing a publishing and printing web portal. EasternEuropean Journal of Enterprise Technologies. № 2/2 (92), pp. 14 - 22. DOI: 10.15587/17294061.2018.126305

6. Hrabovskyi Y., Brynza N, Vilkhivska O. (2020). Development of information visualization methods for use in multimedia applications. EUREKA: Physics and Engineering. № 1 , pp. $3-17$.

7. Martins P., Zacarias M. A. (2017). Web-based Tool for Business Process Improvement. International Journal of Web Portals. Vol. 9. Issue 1. P. 68 - 84 DOI: https://doi.org/10.4018/IJWP.2017070104

8. Hrabovskyi Y. M. (2019). Analiz vy`kory`stannya mul'ty`medijny`x komponentiv $v$ suchasny` $x$ texnologiyax mobil 'nogo navchannya. [Analysis of the use of multimedia components in modern technologies of mobile learning]. Scientific Journal "ScienceRise". No. 4 (57), pp. 46-50.

9. Naumenko M. O. (2018). Vdoskonalennya upravlinnya yakistyu produkciyi vy`sokotexnologichny`x pidpry yemstv. [Improvement of product quality management of high-tech enterprises. Bulletin of the Economics of Transport and Industry. No. 62 , pp. $335-342$.

10. Kalycheva N.Ie., Maslova V.O. (2014) Lohistychni pidkhody, yak osnova ratsionalnoi orhanizatsii vyrobnychoho protsesu na pidpryiemstvi [Logistic approaches as a basis for rational organization of production process at the enterprise]. Bulletin of Economics of Transport and Industry. No. 47. Pp. 83 - 86.

11. Kalycheva N.Ie., Kopachevska Yu. A. (2018) Vplyv lohistyky na rozvytok pidpryiemstv maloho biznesu $\mathrm{v}$ suchasnykh umovakh hospodariuvannia. [The influence of logistics on the development of small business in modern conditions of management]. UzhNU Scientific Bulletin. Series: International Economic Relations and the World Economy. Issue 20. Part 2. Pp. 11 - 14. 